\title{
IMPLEMENTASI MODEL PEMBERDAYAAN KARYAWAN (EMPLOYEE EMPOWERMENT) DI PT FIFGROUP TBK CABANG PALEMBANG
}

\author{
Ega Leovani \\ Fakultas Bisnis dan Akuntansi Universitas Katolik Musi Charitas Palembang \\ Email: egaleovani@yahoo.com
}

\begin{abstract}
The objective of this research is to observe the implementation of employee empowerment model at PT. FIF Group in Palembang region. Descriptive analysis was used in this study. The primary data were collected by using questionare. The sample of this study was 74 respondent. Which were selected by using proportional cluster random sampling method. The analysis used employee's perception about empowerment. The result of this research indicates that empowerment is good. The most dominant employee empowerment was accountablity. Meanwhile the lowest were trust and confidence.
\end{abstract}

Keywords: Empowerment, Employee

Abstrak: Penelitian ini bertujuan mengetahui implementasi pemberdayaan karyawan (Employee Empowerment) di PT. FIF Group Cabang Palembang. Penelitian ini menggunakan analisis deskriptif. Sumber data yang dipergunakan dalam penelitian ini adalah data primer, yaitu data yang diperoleh langsung dari sumbernya dengan cara menyebarkan kuesioner. Pengumpulan data di lakukan dengan metode kuesioner, sampel pada penelitian ini berjumlah 74 responden dengan metode proportional cluster random sampling. Berdasarkan hasil analisis dapat diketahui bahwa secara keseluruhan pemberdayaan karyawan P.T. FIF Group Cabang Palembang sudah baik. Pemberdayaan karyawan yang paling dominan adalah accountability. Sedangkan pemberdayaan yang terendah adalah trust dan confident.

Kata Kunci:Pemberdayaan, Karyawan

\section{PENDAHULUAN}

Salah satu kunci untuk meningkatkan kinerja perusahaan adalah melibatkan lebih banyak dan lebih dalam lagi sumber daya manusia ke dalam pekerjaan-pekerjaan dalam perusahaan. Untuk hal kepentingan ini, peranan para pimpinan perusahaan untuk mengubah dan menciptakan suasana kerja yang kondusif sangat besar dan penting. Meskipun sekarang ini sering dikatakan sebagai era teknologi, namun untuk memajukan dan meningkatkan kinerja perusahaan yang menjadi sumber terpenting adalah sumberdaya manusia yang ada di dalamnya. Tingkat dedikasi, komitmen dan kompetensi orang-orang yang bekerja itu yang akan menentukan sampai seberapa jauh perusahaan akan mampu meningkatkan kinerjanya. Pemberdayaan adalah cara untuk menciptakan suasana kerja yang kondusif untuk meningkatkan kinerjanya. Pemberdayaan (empowerment) adalah proses membangun dedikasi dan komitmen yang tinggi sehingga organisasi itu bisa menjadi sangat efektif dalam mencapai tujuan-tujuannya. 
Dalam organisasi yang telah diberdayakan akan tercipta hubungan di antara orangorangnya yang saling berbagi kewenangan, tanggung jawab, komunikasi, harapanharapan, pengakuan, dan penghargaan. Menurut Sedarmayanti (2000:123) pemberdayaan sumber daya manusia merupakan salah satu upaya yang wajib dilakukan bagi terciptanya sumber daya manusia yang berkualitas, memiliki kemampuan memanfaatkan, mengembangkan dan menguasai ilmu pengetahuan dan tekhnologi serta kemampuan menajemen.

Hanya karyawan yang mendapatkan pemberdayaan secara benar akan memiliki kompetensi yang lebih baik. Program pemberdayaan karyawan dituntut untuk bisa memberdayakan karyawan agar memiliki tanggung jawab dan ketrampilan kerja yang lebih besar. Pemberdayaan karyawan pada dasarnya membentuk karyawan produktif dan berkomitmen. Sebab dalam bisnis harus diperhatikan pula kondisi lingkungan kerja sehingga dapat memberikan peningkatan terhadap upaya pemberdayaan. Organisasi yang berdaya akan dipenuhi oleh orang-orang yang memiliki kepedulian dan keterlibatan yang dapat membantu usaha pencapaian fleksibilitas, responsivitas terhadap pelanggan, dalam lingkungan bisnis yang menantang dan kompetitif. Seperti dikatakan oleh Blancard (2002) bahwa pemberdayaan sebagai suatu cara untuk mewirausahakan (entrepreneurship) orang lain, penanaman rasa memiliki (ownership), suatu bentuk ikatan kerja atas dasar komitmen (engagement), dan sebagai suatu usaha untuk membuat orang lain terlibat (involvement). Permasalah dalam penelitian ini adalah bagaimana implementasi model pemberdayaan karyawan pada PT. FIF GROUP Cabang Palembang?

Tujuan penelitian ini adalah untuk mengetahui implementasi model pemberdayaan karyawan pada PT. FIF GROUP Cabang Palembang. Temuan penelitian ini di harapkan dapat memperkaya pengetahuan mengenai pemberdayaan karyawan. Selain itu penelitian ini dapat sebagai masukan tentang pemberdayaan karyawan yang bekerja pada PT. FIF GROUP Cabang Palembang, sehingga nantinya dapat meningkatkan kinerja karyawan yang dapat mencapai tujuan organisasi yaitu meningkatkan keuntungan bagi perusahaan. Untuk pengembangan ilmu pengetahuan, hasil penelitian ini akan dapat dijadikan sebuah referensi untuk penelitian selanjutnya dan dapat memperkaya bahan ajar kepada mahasiswa dalam hal pemberdayaan karyawan.

\section{KAJIAN TEORI}

Pada hakekatnya konsep pemberdayaan merupakan pengembangan dari teori manajemen partisipatif (Participative Management). Partisipasimerupakan proses yang dilakukan organisasi untuk memberikan kesempatan bagi karyawan untuk berperan serta dalam mengambil keputusan-keputusan tentang pekerjaan mereka. Pemberdayaan mengandung pengertian yang lebih luas dari partisipasi, dan pengertian tersebut berkembang terus sejalan dengan perkembangan teori-teori manajemen dan perilaku organisasi.

Menurut Mulyadi, (2000:103), pemberdayaan berarti memampukan (to able), memberi kesempatan (to allow), dan mengijinkan (to permit) yang dapat diartikan baik melalui inisiatif sendiri maupun dipicu orang lain. Pemberdayaan pegawai berarti memampukan dan memberi kesempatan kepada pegawai untuk melakukan fungsi-fungsi manajemen dalam skala yang menjadi tanggungjawabnya, baik secara individu maupun kelompok. Gibson et al (2006) bahwa pemberdayaan karyawan (individual empowerment) adalah pemberian kesempatan dan dorongan kepada para karyawan untuk 
mendayagunakan bakat, ketrampilan-ketrampilan, sumberdaya-sumberdaya, dan pengalaman-pengalaman mereka untuk menyelesaikan pekerjaan secara tepat waktu. Hasil-hasil yang dicapai dalam menerapkan konsep pemberdayaan di berbagai perusahaan adalah peningkatan efisiensi dan kualitas dalam produksi dan pelayanan.

Khan (1997) menawarkan sebuah model pemberdayaan yang dapat dikembangkan dalam sebuah organisasi. Model pemberdayaan tersebut yaitu: (1) Desire. Tahap pertama dalam model pemberdayaan (empowerment)adalah adanya keinginan dari manajemen untuk mendelegasikan dan melibatkan pekerjaan. Yang termasuk hal ini antara lain: (a) Pekerja diberi kesempatan untuk mengidentifikasikan permasalahan yang sedang berkembang; (b) Memperluas keterlibatan pekerja; (c) Mendorong terciptanya perspektif baru dan memikirkan strategi kerja; (d) Menggambarkan keahlian tim dan melatih karyawan untuk mengawasi sendiri. (2) Trust. Setelah adanya keinginan dari manajemen untuk melakukan pemberdayaan, langkah selanjutnya adalah membangun kepercayaan antara manajemen dan karyawan. Adanya saling percaya diantara anggota organisasi akan tercipta kondisi yang baik untuk pertukasan informasi dan saran adanya rasa takut. Hal-hal yang termasuk dalam trust antara lain: (a) Memberi kesempatan pada karyawan untuk berpartisipasi dalam pembuatan kebijakan; (b) Menyediakan waktu dan sumber daya yang mencukupi bagi karyawan dalam menyelesaikan kerja; (c) Menyediakan pelatihan yang mencukupi bagi kebutuhan kerja; (d) Menghargai perbedaan pandangan dan menghargai kesuksesan yang diraih oleh karyawan; (e) Menyediakan akses informasi yang cukup.

(2) Confident. Langkah selanjutnya setelah adanya saling percaya adalah menimbulkan rasa percaya diri karyawan dengan menghargai terhadap kemampuan yang dimiliki oleh karyawan. Hal yang termasuk tindakan yang dapat menimbulkan confident antara lain: (a) Mendelegasikan tugas yang penting kepada karyawan; (b) Menggali ide dan saran dari karyawan; (c) Memperluas tugas dan membangun jaringan antara departemen; (d) Menyediakan jadwal instruksi pekerjaan dan mendorong penyelesaian yang baik. (3) Credibility. Langkah keempat menjaga kredibilitas dengan penghargaan dan mengembangkan lingkungan kerja yang mendorong kompetisi yang sehat sehingga terciptanya organisasi yang memiliki kinerja yang tinggi. Hal yang termasuk credibility antara lain: (a) Memandang karyawan sebagai partner strategis; (b) Peningkatan target di semua bagian pekerjaan; (c) Memperkenalkan inisiatif individu untuk melakukan perubahan melalui partisipasi; (d) Membantu menyelesaikan perbedaan-perbedaan dalam penentuan tujuan dan prioritas. (4) Accountability. Tahap dalam proses pemberdayaan selanjutnya adalah pertanggung jawaban karyawan pada wewenang yang diberikan. Dengan menetapkan secara konsisten dan jelas tentang peran, standard dan tujuan tentang penilaian terhadap kinerja karyawan, tahap ini sebagai sarana evaluasi terhadap kinerja karyawan dalam penyelesaian dan tanggung jawab terhadap wewenang yang diberikan. Hal ini yang termasuk accountability antara lain: (a) Menggunakan jalur pelatihan (training)dalam mengevaluasi kinerja karyawan; (b) Memberikan tugas yang jelas dan ukuran yang jelas; (c) Melibatkan karyawan dalam penentuan standar dan ukuran; (d) Memberikan bantuan kepada karyawan dalam penyelesaian beban kerja.

(5) Communication. Langkah terakhir adalah adanya komunikasi yang terbuka untuk menciptakan saling memahami antara karyawan dan manajemen. Keterbukaan ini dapat diwujudkan dengan adanya kritik dan saran terhadap hasil dan prestasi yang dilakukan pekerja. Hal yang termasuk dalam communication antara lain: (a) Menetapkan kebijakan komunikasi terbuka (open door communication);(b)Menyediakan waktu untuk 
mendapatkan informasi dan mendiskusikan permasalahan secara terbuka; (c) Menciptakan kesempatan untuk pelatihan silang (cross training).

Model di atas menggambarkan bahwa sebuah pemberdayaan merupakan serangkaian proses yang dilakukan secara bertahap dalam organisasi agar dapat dicapai secara optimal dan membangun kesadaran dari anggota organisasi akan pentingnya proses pemberdayaan sehingga perlu adanya komitmen dari anggota terhadap organisasi. Dengan pemberian wewenang dan tanggung jawab akan menimbulkan motivasi dan komitmen karyawan terhadap organisasi.

Penelitian terdahulu oleh Debora (2006) yang berjudul "Pengaruh Pemberdayaan Kerja dan Psikologis Terhadap Kepercayaan Organisasional dan Kepuasan Kerja Dosen Tetap Perguruan Tinggi Swasta". Dari hasil penelitian, hasil analisis deskriptif menunjukkan bahwa secara umum pemberdayaan kerja, pemberdayaan psikologis, kepercayaan organisasional dan kepuasan kerja dosen tetap perguruan tinggi swasta berada dalam kondisi sedang. Selanjutnya, akses informasi, akses sumber daya, akses dukungan dan akses peluang di lingkungan kerja merupakan faktor penting pembentuk pemberdayaan kerja. Secara umum perhatian pimpinan perguruan tinggi swasta terhadap akses sumberdaya paling rendah dibandingkan dengan akses yang lain. Kenyataan yang ada menunjukkan bahwa sebuah perguruan tinggi yang berstatus swasta tidak semuanya memiliki akses sumberdaya yang cukup memadai. Hasil analisis statistik inferensial dengan menggunakan Structural Equation Modeling (SEM), dari model yang disajikan dalam 6 (enam) hipotesis pada penelitian ini, terbukti semua dapat, diterima dengan hasil adanya pengaruh yang positif dan signifikan.

Kerangka Teori. Pemberdayaan sumber daya manusia merupakan salah satu upaya yang wajib dilakukan bagi terciptanya sumber daya manusia yang berkualitas, memiliki kemampuan memanfaatkan, mengembangkan dan menguasai ilmu pengetahuan dan teknologi serta kemampuan menajemen. Tahap pertama dalam model pemberdayaan (empowerment) karyawan PT FIF GROUP Cabang Palembang adalah adanya keinginan dari manajemen untuk mendelegasikan dan melibatkan pekerjaan. Setelah adanya keinginan dari manajemen untuk melakukan pemberdayaan, langkah selanjutnya adalah membangun kepercayaan antara manajemen dan karyawan. Adanya saling percaya diantara anggota organisasi akan tercipta kondisi yang baik untuk pertukaran informasi dan saran adanya rasa takut.

Langkah selanjutnya setelah adanya saling percaya adalah menimbulkan rasa percaya diri karyawan dengan menghargai terhadap kemampuan yang dimiliki oleh karyawan. Langkah keempat menjaga kredibilitas dengan penghargaan dan mengembangkan lingkungan kerja yang mendorong kompetisi yang sehat sehingga terciptanya organisasi yang memiliki kinerja yang tinggi. Tahap dalam proses pemberdayaan selanjutnya adalah pertanggung jawaban karyawan pada wewenang yang diberikan. Dengan menetapkan secara konsisten dan jelas tentang peran, standar dan tujuan tentang penilaian terhadap kinerja karyawan, tahap ini sebagai sarana evaluasi terhadap kinerja karyawan dalam penyelesaian dan tanggung jawab terhadap wewenang yang diberikan. Langkah terakhir adalah adanya komunikasi yang terbuka untuk menciptakan saling memahami antara karyawan dan manajemen PT FIF GROUP Cabang Palembang. Keterbukaan ini dapat diwujudkan dengan adanya kritik dan saran terhadap hasil dan prestasi yang dilakukan pekerja. 


\section{Model Penelitian}

\begin{tabular}{|ll|}
\hline Model Pemberdayaan Karyawan PT \\
FIF GROUP Cabang Palembang & \\
& \\
1. Desire & \\
2. Trust & \\
3. Confident & \\
4. Credibility & \\
5. Accontability & \\
6. Communication & \\
\hline
\end{tabular}

Gambar 1. Model Penelitian

Sumber: Khan (1997)

\section{METODE}

Jenis penelitian ini adalah penelitian deskriptif (descriptive research) untuk memperoleh gambaran persepsi responden sesuai dengan variabel yang diteliti yaitu pemberdayaan karyawan PT FIF GROUP Cabang Palembang. Menurut Nazir (2007:125) metode penelitian deskriptif adalah suatu metode dalam meneliti status kelompok manusia, satu objek, satu kondisi, dengan satu sistem pemikiran pada masa sekarang. Tujuan penelitian deskriptif adalah untuk membuat gambaran atau lukisan secara sistematis, aktual dan akurat mengenai fakta-fakta sifat, serta hubungan antara fenomena yang diselidiki.

Pada umumnya penelitian deskriptif merupakan penelitian yang non hipotesis sehingga dalam rangka penelitiannya bahkan tidak perlu merumuskan hipotesisnya (Arikunto, 2001). Metode penelitian deskriptif adalah metode yang digunakan untuk mendapatkan gambaran keseluruhan obyek penelitian secara akurat. Pelaksanaan metode penelitian deskriptif tidak terbatas hanya sampai pada pengumpulan dan penyusunan data, tetapi meliputi analisis dan interpretasi tentang arti data tersebut. Selain itu, semua data yang dikumpulkan berkemungkinan menjadi kunci terhadap apa yang diteliti (Moleong, 2000). Mengacu pada tujuan penulisan ini yaitu untuk menggambarkan pemberdayaan karyawan PT FIF GROUP Cabang Palembang.

Jenis dan Sumber Data. Secara definitif, data didefinisikan sebagai fakta-fakta yang diperoleh oleh peneliti yang berasal dari lingkungan penelitian (Cooper dan Schindler, 2001:82). Sumbernya data yang dipergunakan dalam penelitian ini adalah data primer, yaitu data yang diperoleh langsung dari sumbernya dengan cara menyebarkan kuesioner. Dalam penelitian data primer diperoleh yaitu data yang diperoleh langsung dari objek penelitian melalui kuesioner yang disebarkan pada pemberdayaan karyawan PT FIF GROUP Cabang Palembang.

Metode Pengumpulan Data. Alat untuk mengumpulkan data adalah daftar pertanyaan, yang sering disebutkan secara umum dengan nama kuesioner. Pertanyaan-pertanyaan yang terdapat dalam kuesioner, atau daftar pertanyaan tersebut cukup terperinci dan lengkap. Populasi dan Sampel. Populasi penelitian ini adalah karyawan PT FIF GROUP Cabang Palembang yang terbagi dalam tujuh bagian, yang keseluruhannya berjumlah 240 orang karyawan. Sampel pada penelitian ini dengan metode proportional cluster random 
sampling, dimana populasi dikelompokkan berdasarkan bagian masing-masing, lalu masing-masing bagian akan diambil beberapa sampel dengan metode simple random sampling (Sekaran, 2000:283). Untuk itu sampel akan diambil sebanyak 30\% dari jumlah populasi sebanyak 240 orang yaitu 74 orang responden berdasarkan region atau bagian seperti yang ditunjukkan Tabel 1.

Tabel 1. Jumlah Populasi dan Sampel penelitian

\begin{tabular}{clcc}
\hline No & \multicolumn{1}{c}{ Biro-Biro } & Populasi & Sampel (30\% dari Populasi) \\
\hline 1 & Departemen HRD, GA, dan Finance & 15 & 5 \\
2 & Departemen Marketing & 25 & 8 \\
3 & Departemen Kredit & 48 & 14 \\
4 & Departemen Collection & 99 & 30 \\
5 & Departemen Remidial & 39 & 12 \\
6 & Departemen Litigasi & 5 & 2 \\
7 & Departemen Reposession Inventory & 9 & 3 \\
\multicolumn{2}{r}{ Jumlah } & 240 & 74 \\
\hline
\end{tabular}

Sumber: PT FIF Group Palembang, September 2014.

Teknik Analisis Data. Metode analisis deskriptif yaitu metode analisis berupa uraianuraian yang tidak menggunakan hasil analisis data, tetapi menggunakan tabel-tabel. Teknik analisis deskriptif akan menganalisis distribusi frekuensi, dan rata-rata (mean). Pada tahapan selanjutnya dilakukan teknik analisis data kualitatif setiap data diberikan pengertian sehingga mudah untuk dipahami. Pengertian ini dimaksudkan untuk menganalisis inti pemikiran yang ada dalam data. Adapun teknik yang dapat dilakukan yaitu:Reduksi data yaitu melakukan penyusunan data yang diperoleh, kemudian ditentukan data yang sesuai dengan penelitian ini dengan pengklasifikasian yang ada. Sementara data yang kurang relevan dikesampingkan.Pengklasifikasian data dalam beberapa tolak ukur dengan menggunakan pendekatan-pendekatan teori-teori pada penelitian.Dilakukan penyimpulan sebagai langkah awal untuk membuat kesimpulan akhir dari penelitian ini. Kerangka analisis digunakan sebagai asumsi-asumsi untuk menghasilkan kesimpulan-kesimpulan sementara dalam penelitian ini. Penggabungan antara kerangka pikir dan teori-teori yang ada dengan kondisi obyektif hasil penelitian kemudian dijadikan pedoman untuk melakukan penyimpulan akhir.

\section{HASIL DAN PEMBAHASAN}

Gambaran UmumPT FIF Group. FIFGROUP adalah grup manajemen dari beberapa perusahaan yang memiliki unit bisnis yang berbeda-beda. FIFGROUP saat ini menaungi PT Federal International Finance dan PT Astra Multi Finance. Jasa layanan pembiayaan ini meliputi metode pembiayaan konvensional maupun syariah. FIFGROUP hadir untuk mengakomodir keanekaragaman kebutuhan masyarakat Indonesia dengan senantiasa berpegang pada prinsip inovasi dan kreativitas. 'Mengubah tantangan menjadi peluang' adalah landasan pemikiran yang membuat FIFGROUP terus berkembang.

Karakteristik Demografi Responden. Karakteristik responden berdasarkan rentang usia sebagian besar responden berada pada rentang usia 21-30 tahun sebanyak 43 orang (58.1\%). Hal ini menunjukkan bahwa sebagian besar karyawan PT. FIFGroup Cabang Palembang berada pada usia yang dianggap matang dan produktif. Dengan demikian 
diharapkan karyawan mampu membangun komunikasi kerja yang baik dan terbuka, serta memiliki mobilitas kerja yang tinggi sehingga mampu mencapai target terutama target penjualan dan pelaporan yang telah ditentukan. Selanjutnya, dapat diketahui karakteristik demografi responden pada penelitian ini yaitu sebanyak 52 orang responden laki-laki (70.3\%), dan sebanyak 22 orang responden perempuan (29.7\%). Pada penelitian ini lebih banyak karyawan laki-laki karena memang dibutuhkan untuk ditugaskan di lapangan misalnya field verivier yang bertugas memverifikasi data calon debitur/ calon konsumen, field collector yang bertugas mengunjungi debitur dengan harapan mengetahui kondisi debitur beserta kondisi keuangannya dan memberikan pengertian secara persuasif mengenai kewajiban debitur dalam hal melakukan pembayaran angsuran,dan Re-medial Collector yang bertugas untuk mengambil barang jaminan debitur apabila debitur tidk juga dapat menyelesaikan tunggakannya.Karakteristik responden berdasarkan tingkat pendidikan dapat diketahui bahwa latar belakang pendidikan sebagian besar responden adalah 40 orang atau (54.1\%) berpendidikan SMA/ Sederajat, dan 25 orang (33.8\%) sarjana S1. Pendidikan yang dimiliki oleh karyawan yang tinggi akan sangat menentukan kemampuan kerja karyawan tersebut dalam menyelesaikan pekerjaan yang dibebankan kepadanya. Dengan tingkat latar belakang pendidikan yang tinggi tersebut diharapkan karyawan mampu menyelesaikan pekerjaan dengan baik mampu mencapai target kerja yang telah ditentukan.Karakteristik responden berdasarkan rentang masa kerja, sebagian besar responden berada pada rentang masa kerja 2-5 tahun sebanyak 30 orang (40.5\%). Hal ini menunjukkan bahwa sebagian besar responden yang diteliti sudah bekerja cukup lama sebagai karyawan pada PT FIF Group Cabang Palembang. Dengan demikian diharapkan memiliki pengalaman kerja cukup lama sehingga mampu menyelesaikan pekerjaan dengan baik dan mencapai target kerja yang telah ditentukan.

Tabel 2. Tanggapan Karyawan Terhadap Desire

\begin{tabular}{|c|c|c|c|c|c|c|c|c|}
\hline \multirow[t]{2}{*}{ No } & \multirow[t]{2}{*}{ Pernyataan } & \multicolumn{5}{|c|}{ Skor Jawaban } & \multirow{2}{*}{$\begin{array}{l}\text { Rata- } \\
\text { Rata }\end{array}$} & \multirow[t]{2}{*}{ Ket } \\
\hline & & SS & $\mathrm{S}$ & CS & TS & STS & & \\
\hline 1 & $\begin{array}{l}\text { Sebagai karyawan Saudara diberi } \\
\text { kesempatan untuk } \\
\text { mengidentifikasikan permasalahan } \\
\text { yang sedang berkembang berkaitan } \\
\text { dengan pekerjaan Saudara }\end{array}$ & 12 & 25 & 24 & 13 & - & 3.49 & diberdayakan \\
\hline 2 & $\begin{array}{l}\text { PT FIF Group Cabang Palembang } \\
\text { memperluas keterlibatan Saudara } \\
\text { sebagai karyawan dalam bekerja }\end{array}$ & 2 & 33 & 39 & - & - & 3.5 & diberdayakan \\
\hline 3 & $\begin{array}{l}\text { PT FIF Group Cabang Palembang } \\
\text { mendorong Saudara sebagai } \\
\text { karyawan menciptakan perspektif } \\
\text { baru dan memikirkan strategi kerja } \\
\text { perusahaan }\end{array}$ & - & 1 & 54 & 19 & - & 2,76 & $\begin{array}{c}\text { Cukup } \\
\text { diberdayakan }\end{array}$ \\
\hline 4 & $\begin{array}{l}\text { PT FIF Group Cabang Palembang } \\
\text { menggambarkan keahlian tim dan } \\
\text { melatih Saudara sebagai karyawan } \\
\text { dalam melaksanakan pekerjaan }\end{array}$ & 22 & 16 & 36 & - & - & 3,81 & diberdayakan \\
\hline & Rerata & & & & & & 3,39 & $\begin{array}{l}\text { Cukup } \\
\text { diberdayakan }\end{array}$ \\
\hline
\end{tabular}

Sumber: Penelitian, 2015 
Tanggapan karyawan terhadap desirererata jawaban responden secara keseluruhan sebesar 3,39 (2.61-3.4 = Cukup diberdayakan), hal ini menunjukkan bahwa adanya keinginan dari manajemen PT FIF Group Cabang Palembang untuk mendelegasikan dan melibatkan pekerjaan melalui identifikasi masalah, memperluas keterlibatan sebagai karyawan, mendorong karyawan menciptakan perspektif baru dan memikirkan strategi kerja perusahaan, menggambarkan keahlian tim dan melatih karyawan dalam melaksanakan pekerjaan. Rata-rata jawaban tertinggi responden sebesar 3,81 (3,41-4,20 = Diberdayakan) untuk pernyataan "PT FIF Group Cabang Palembang menggambarkan keahlian tim dan melatih Saudara sebagai karyawan dalam melaksanakan pekerjaan”, artinya rata-rata jawaban adalah baik. Hal ini menandakan bahwa memang ada penggambaran keahlian tim dan melatih karyawan untuk mengawasi diri sendiri dalam melaksanakan pekerjaan berupa target yang harus dicapai tim misalnya tim collection.

Selanjutnya, tanggapan terendah responden sebesar 2,76 (2,61-3,40 = Cukup Diberdayakan) untuk pernyataan "PT FIF Group Cabang Palembang mendorong Saudara sebagai karyawan menciptakan perspektif baru dan memikirkan strategi kerja perusahaan”, artinya rata-rata jawaban adalah kurang baik. Ini menandakan bahwa tidak ada dorongan bagi karyawan menciptakan perspektif baru dan memikirkan strategi kerja perusahaan. Ini karena semua strategi kerja sudah dibuat dan ditentukan oleh manajemen PT FIF Group.

Tabel 3. Tanggapan Karyawan Terhadap Trust

\begin{tabular}{|c|c|c|c|c|c|c|c|c|}
\hline \multirow[t]{2}{*}{ No } & \multirow[t]{2}{*}{ Pernyataan } & \multicolumn{5}{|c|}{ Skor Jawaban } & \multirow{2}{*}{$\begin{array}{l}\text { Rata- } \\
\text { Rata }\end{array}$} & \multirow[t]{2}{*}{ Ket } \\
\hline & & SS & $\mathrm{S}$ & CS & TS & STS & & \\
\hline 1 & \begin{tabular}{lrr} 
PT. FIF & Group & Cabang \\
Palembang & \multicolumn{2}{c}{ memberikan } \\
kesempatan & pada & Saudara \\
sebagai karyawan & untuk \\
berpartisipasi dalam pembuatan \\
kebijakan berkaitan & dengan \\
pekerjaan Saudara
\end{tabular} & - & 2 & 43 & 29 & - & 2,64 & $\begin{array}{c}\text { Cukup } \\
\text { diberdayakan }\end{array}$ \\
\hline 2 & $\begin{array}{l}\text { PT. FIF Group Cabang } \\
\text { Palembang menyediakan waktu } \\
\text { dan sumber daya misalnya } \\
\text { peralatan kerja yang mencukupi } \\
\text { bagi Saudara sebagai karyawan } \\
\text { dalam menyelesaikan kerja }\end{array}$ & 5 & 36 & 33 & - & - & 3,62 & diberdayakan \\
\hline 3 & $\begin{array}{l}\text { PT. FIF Group Cabang } \\
\text { Palembang menyediakan } \\
\text { pelatihan yang mencukupi bagi } \\
\text { kebutuhan kerja Saudara sebagai } \\
\text { karyawan }\end{array}$ & 4 & 61 & 9 & - & - & 3,93 & diberdayakan \\
\hline 4 & $\begin{array}{l}\text { Pimpinan Saudara menghargai } \\
\text { perbedaan pandangan dan } \\
\text { menghargai kesuksesan yang } \\
\text { diraih oleh karyawan }\end{array}$ & - & 31 & 43 & - & - & 3,42 & diberdayakan \\
\hline 5 & $\begin{array}{l}\text { PT. FIF Group Cabang } \\
\text { Palembang menyediakan akses } \\
\text { informasi yang cukup dalam } \\
\text { bekerja }\end{array}$ & - & 27 & 46 & 1 & - & 3,35 & diberdayakan \\
\hline & Rerata & & & & & & 3,39 & diberdayakan \\
\hline
\end{tabular}

Sumber: Penelitian 2015 
Tanggapan karyawan terhadap trustrerata jawaban responden secara keseluruhan sebesar 3,39 (3,41-4,20 = Diberdayakan), hal ini menunjukkan bahwa antara manajemen PT. FIF Group Cabang Palembang dan karyawan membangun kepercayaan. Adanya saling percaya di antara anggota organisasi akan tercipta kondisi yang baik.

Rata-rata jawaban tertinggi responden sebesar 3,96 (3,41-4,20 = Diberdayakan) untuk pernyataan "PT FIF Group Cabang Palembang menyediakan pelatihan yang mencukupi bagi kebutuhan kerja Saudara sebagai karyawan”, artinya rata-rata jawaban adalah baik. Hal ini menandakan bahwa memang PT FIF Group Cabang Palembang menyediakan pelatihan bagi para karyawan. Tingginya pernyataan ini karena karyawan diberikan pelatihan misalnya pelatihan "know your customer" bagi semua karyawan terutama karyawan verivier yang bertugas memverivikasi data calon konsumen yang jika kemudian akan menjadi konsumen untuk dapat dipastikan ketepatan waktu dalam proses pembayaran angsuran. Tak hanya bagi karyawan operasional saja, PT. FIF Group pun memberikan pelatihan kepada karyawan "key people” pelatihan leadership for manager, balanced scorecard dan traning for trainer.

Selanjutnya, tanggapan terendah responden sebesar 2,64 (2,61-3,4 = cukup diberdayakan) untuk pernyataan "PT FIF Group Cabang Palembang memberikan kesempatan pada Saudara sebagai karyawan untuk berpartisipasi dalam pembuatan kebijakan berkaitan dengan pekerjaan Saudara”, artinya rata-rata jawaban adalah baik. Hal ini menandakan bahwa pelibatan atau partisipasi karyawan dalam pembuatan kebijakan berkaitan dengan pekerjaan tidak terlalu banyak, karena PT FIF Group telah memiliki juklak dalam melaksanakan pekerjaannya sesuai dengan sistem yang ada, adapaun untuk beberapa kasus kebijakan hanya dapat di ambil oleh "key people" cabang dengan pengajuan memo ke Departemen Head kantor pusat bagian terkait.

Berdasarkan hasil tanggapan responden tentang pemberdayaan dari dimensi trust yaituadanya saling percaya di antara anggota organisasi. Tetapi kebijakan sudah ditentukan oleh pihak manajemen PT FIF Group Head Office kecuali apabila memang ada kasus tertentu yang di haruskan adanya tindakan pengecualian di luar juklak yang ada, hal ini pun harus mendapatkan persetujuan terlebih dahulu dari Departemen Head terkait di Head Office. Pihak FIF Group menyediakan sumber daya yang diperlukan misalnya komputer bagi karyawanback office, handpone dengan jaringan internet dan tunjangan pulsa bagi karyawan yang bertugas di lapangan. Setiap karyawan diberikan pelatihan berupa pengetahuan tentang produk, sistem kerja dan standarkerja. Perbedaan sangat dihargai di FIF Group misalnya untuk penghitungan Bonus Akhir Tahun (BAT) bagi karyawan berprestasi dan bekerja selalu melampaui target.

Tabel 4. Tanggapan Karyawan Terhadap Confident

\begin{tabular}{|c|c|c|c|c|c|c|c|c|}
\hline \multirow[t]{2}{*}{ No } & \multirow[t]{2}{*}{ Pernyataan } & \multicolumn{5}{|c|}{ Skor Jawaban } & \multirow{2}{*}{$\begin{array}{l}\text { Rata- } \\
\text { Rata }\end{array}$} & \multirow[t]{2}{*}{ Ket } \\
\hline & & SS & $\mathrm{S}$ & CS & TS & STS & & \\
\hline 1 & $\begin{array}{l}\text { PT. FIF Group } \\
\text { Palembang melalui masing } \\
\text { masing Section } \\
\text { mendelegasikan tugas yang } \\
\text { penting kepada karyawan dalam } \\
\text { melaksanakan pekerjaan }\end{array}$ & - & 7 & 39 & 28 & - & 2,72 & $\begin{array}{c}\text { cukup } \\
\text { diberdayakan }\end{array}$ \\
\hline 2 & $\begin{array}{l}\text { Pimpinan Saudara menggali ide } \\
\text { dan saran dari karyawan dalam } \\
\text { melaksanakan breefing }\end{array}$ & - & 32 & 42 & - & - & 3,43 & diberdayakan \\
\hline
\end{tabular}


Leovani: Implmentasi Model Pemberdayaan Karyawan (Employee Empowerment)...

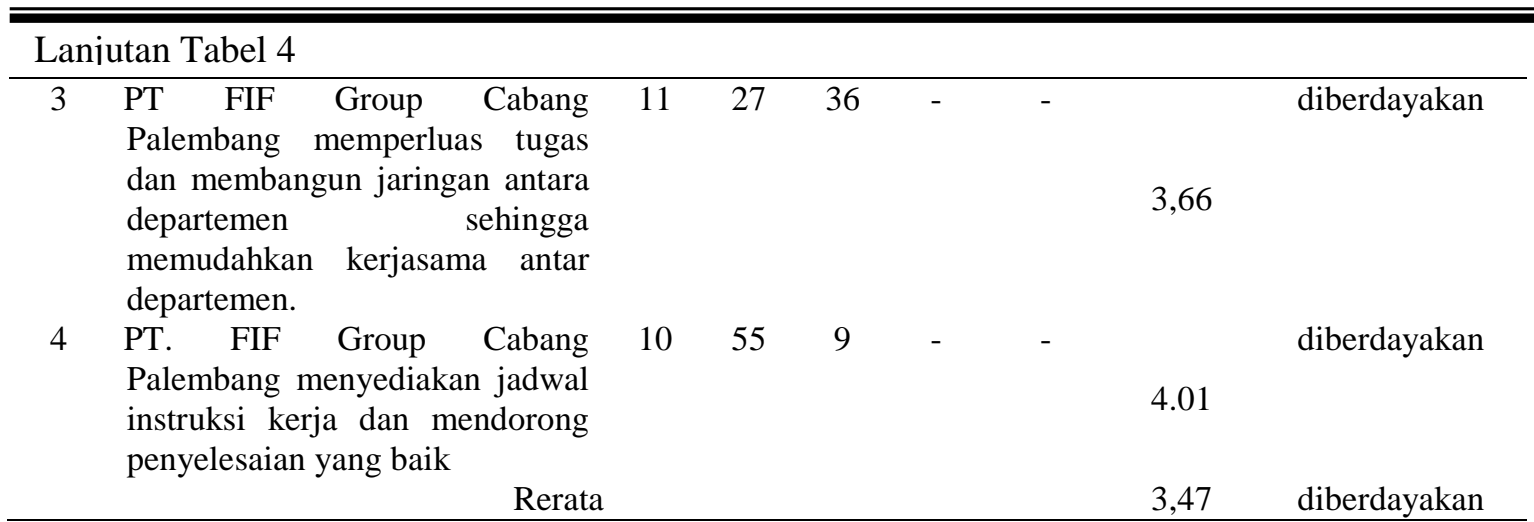

Sumber: Penelitian 2015

Tanggapan karyawan terhadap confidentrerata jawaban responden secara keseluruhan sebesar 3,47 (3,41-4,20 = Diberdayakan), hal ini menunjukkan bahwa manajemen menimbulkan rasa percaya diri karyawan dengan menghargai kemampuan yang dimiliki oleh karyawan.Rata-rata jawaban tertinggi responden sebesar 4,01 (3,41-4,20 = Diberdayakan) untuk pernyataan "PT. FIF Group Cabang Palembang menyediakan jadwal instruksi kerja dan mendorong penyelesaian yang baik”, artinya rata-rata jawaban adalah baik. Hal ini menandakan bahwa memang karyawan mendapat jadwal instruksi misalnya setiap awal bulan section head akan mendapatkan beban tagih, beban tarik, dan pelunasan khusus yang di berikan oleh departemen remidial HO, kemudian section head akan mulai melakukan clustering beban kepada semua supervisor remidial, tahap berikutnya setiap supervisor akan kembali melalukan clustering beban kepada field remidial sesuai dengan cycle setiap field remidial di minta untuk membuat forcasting mengenai jadwal kunjungan dan target harian yang akan di capai di bulan berjalan. Semua hal ini dilakukan dengan sistem HRMS (Human Resources Management System).

Selanjutnya, tanggapan terendah responden sebesar 2,72 (2,61-3,40 = Cukup Diberdayakan) untuk pernyataan "PT. FIF Group Cabang Palembang melalui masingmasing section head mendelegasikan tugas yang penting kepada karyawan dalam melaksanakan pekerjaan”, artinya rata-rata jawaban adalah baik. Hal ini menandakan bahwa hampir tidak ada pendelegasian wewenang. Ini karena semua pekerjaan sudah ada SOP dan juklak yang sudah di buat oleh manajemen FIF group dan ada pada system HRMS masing-masing karyawan.

Berdasarkan hasil tanggapan responden tentang pemberdayaan dari dimensi confident manajemen menimbulkan rasa percaya diri karyawan dengan menghargai kemampuan yang dimiliki oleh karyawan, tetapi tidak ada pendelegasian tugas. Selanjutnya ada perluasan tugas seperti verivier yang bertanggung jawab untuk memverivikasi data calon konsumen tidak hanya bertanggung jawab dalam kebenaran data calon konsumen tersebut, tetapi ikut membantu mengingatkan jadwal pembayaran tepat waktu jika calon konsumen tersebut mendapatkan kredit dari FIF Group, maka dari itu kerjasama bagian kredit yang menaungi verivier dan bagian collection yang bertugas menagih tunggakan di bawah 60 hari sangatlah penting. Penggalian ide dan saran banyak di lakukan oleh departemen marketing untuk meningkatkan market share FIF Group, dan departemen collection untuk dapat mengurangi over 60 hari, serta bagian remidial untuk dapat mengurangi jumlah barang aset Write Off atau WO. Jadwal instruksi kerja berupa target penyelesaian dan pengiriman laporan target market, collection dan remidial dapat di lihat dalam HRMS yang akan terhubung dengan atasan langsung dalam satu departemen dan branch manager cabang dan head office. 
Tabel 5. Tanggapan Karyawan Terhadap Credibility

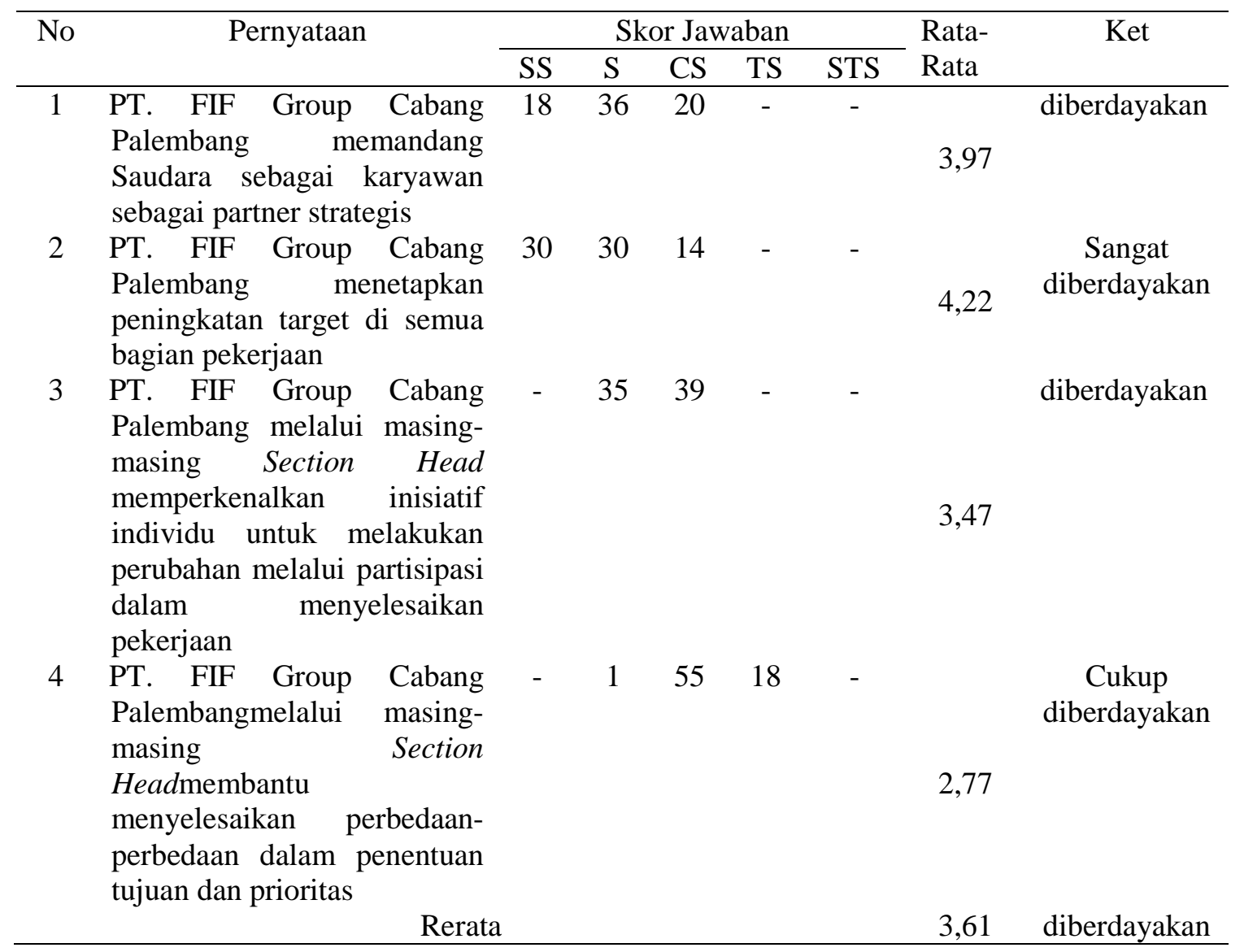

Sumber: Penelitian, 2015

Tanggapan karyawan terhadap credibility rerata jawaban responden secara keseluruhan sebesar 3,61 (3,41-4,20 = Diberdayakan), hal ini menunjukkan bahwa ada kredibilitas yang dijaga dengan penghargaan dan mengembangkan lingkungan kerja yang mendorong kompetisi yang sehat sehingga terciptanya perusahasaan PT FIF Group Cabang Palembang yang memiliki kinerja yang tinggi dengan memandang karyawan sebagai partner strategis, menetapkan peningkatan target di semua bagian pekerjaan, memperkenalkan inisiatif individu dan membantu menyelesaikan perbedaan-perbedaan dalam penentuan tujuan dan prioritas. Rata-rata jawaban tertinggi responden sebesar 4,22 $(4,21-5$ = Sangat diberdayakan) untuk pernyataan "PT FIF Group Cabang Palembang menetapkan peningkatan target di semua bagian pekerjaan”, artinya rata-rata jawaban adalah baik. Hal ini menandakan bahwa memang ada penetapan peningkatan target di semua bagian pekerjaan. Beban tagihan untuk collection dengan status C0-C3 berbeda dengan beban tagih remidial C4-C6, begitupun dengan persentase achievment sebagai pengali untuk menghitung insentif karyawan.

Selanjutnya, tanggapan terendah responden sebesar 2,77 (2,61-3,40 = Cukup Diberdayakan) untuk pernyataan "PT FIF Group Cabang Palembang melalui masingmasing Section Head membantu menyelesaikan perbedaan-perbedaan dalam penentuan tujuan dan prioritas, artinya rata-rata jawaban adalah kurang baik. Hal ini menandakan bahwa hampir tidak ada perbedaan-perbedaan dalam penentuan tujuan dan prioritas, 
karena semua pekerjaan sudah ada SOP dan tersistem di HRMS karyawan, dan juga semua tujuan dan prioritas sudah dibuat oleh pihak manajemen FIF Group.

Tabel 6. Tanggapan Karyawan Terhadap Accountability

\begin{tabular}{|c|c|c|c|c|c|c|c|c|}
\hline \multirow[t]{2}{*}{ No } & \multirow[t]{2}{*}{ Pernyataan } & \multicolumn{5}{|c|}{ Skor Jawaban } & \multirow{2}{*}{$\begin{array}{l}\text { Rata- } \\
\text { Rata }\end{array}$} & \multirow[t]{2}{*}{ Ket } \\
\hline & & SS & $\mathrm{S}$ & CS & TS & STS & & \\
\hline 1 & $\begin{array}{l}\text { PT. FIF Group Cabang } \\
\text { Palembang jalur pelatihan } \\
\text { dalam mengevaluasi kinerja } \\
\text { karyawan }\end{array}$ & 30 & 36 & 8 & - & - & 4,30 & $\begin{array}{c}\text { Sangat } \\
\text { diberdayakan }\end{array}$ \\
\hline 2 & $\begin{array}{l}\text { PT FIF Group Cabang } \\
\text { Palembang melalui masing- } \\
\text { masing Section Head } \\
\text { memberikan tugas yang jelas } \\
\text { dan ukuran yang jelas }\end{array}$ & 35 & 31 & 8 & - & - & 4,36 & $\begin{array}{c}\text { Sangat } \\
\text { diberdayakan }\end{array}$ \\
\hline 3 & $\begin{array}{lr}\text { PT FIF Group } & \text { Cabang } \\
\text { Palembangmelalui } & \text { masing- } \\
\text { masing } & \text { Section } \\
\text { Headmelibatkan karyawan } \\
\text { dalam penentuan standar dan } \\
\text { ukuran }\end{array}$ & - & 45 & 29 & - & - & 2,61 & $\begin{array}{c}\text { Cukup } \\
\text { diberdayakan }\end{array}$ \\
\hline 4 & $\begin{array}{l}\text { PT FIF Group Cabang } \\
\text { Palembangmelalui masing- } \\
\text { masing } \\
\text { Headmemberikan bection } \\
\text { kepada karyawan dalam } \\
\text { penyelesaian beban kerja }\end{array}$ & 13 & 36 & 25 & - & - & 3,84 & diberdayakan \\
\hline & Rerata & & & & & & 3,77 & diberdayakan \\
\hline
\end{tabular}

Sumber: Penelitian 2015

Tanggapan karyawan terhadap accountabilityrerata jawaban responden secara keseluruhan sebesar 3.77 (3,41-4,20 = di berdayakan), hal ini menunjukkan bahwa memang ada pertanggung jawaban karyawan pada wewenang yang diberikan, dengan menetapkan secara konsisten dan jelas tentang peran, standar dan tujuan tentang penilaian terhadap kinerja karyawan, tahap ini sebagai sarana evaluasi terhadap kinerja karyawan dalam penyelesaian dan tanggung jawab terhadap wewenang yang diberikan melalui jalur pelatihan, ukuran tugas atau target yang jelas, dan adanya bantuan kepada karyawan dalam penyelesaian beban kerja. Rata-rata jawaban tertinggi responden sebesar 4.36 (4.21-5.0 = Sangat di berdayakan) untuk pernyataan "PT FIF Group Cabang Palembang melalui masing-masing Section Head memberikan tugas yang jelas dan ukuran yang jelas”, artinya rata-rata jawaban adalah sangat baik. Hal ini menandakan bahwa memang ada tugas yang jelas dan ukuran yang jelas berupa target yang harus dicapai bagi para karyawan administrasi harus bisa menyelesaikan laporan tepat waktu, bagian kredit yaitu target NSA (net service asset) yang meningkat serta market share yang tinggi, untuk bagian collection adalah tidak adanya rolling beban dalam cycle yang lebih tinggi, untuk bagian remidial adalah berkurangnya beban WO (Write Off) dan meningkatnya pelsus (pelunasan Khusus). Tingginya pernyataan ini karena setiap bagian di PT FIF Group Cabang Palembang sudah mendapat target kerja yang telah ditentukan oleh pihak manajemen FIF Group. 
Selanjutnya, tanggapan terendah responden sebesar 2,61 (2,61-3,40 = Cukup diberdayakan) untuk pernyataan "PT FIF Group Cabang Palembang melalui masingmasing Section Head melibatkan karyawan dalam penentuan standar dan ukuran”, artinya rata-rata jawaban adalah. Hal ini menandakan bahwa tidak ada pelibatan karyawan dalam penentuan standar dan ukuran target kerja yang harus dicapai, karena semuanya sudah ditentukan oleh manajemen FIF Group.

Tanggapan karyawan terhadap communication adalah rerata jawaban responden secara keseluruhan sebesar 3,56 (3,41-4,20 = Diberdayakan), hal ini menunjukkan bahwa ada komunikasi yang terbuka untuk menciptakan saling memahami antara karyawan dan manajemen PT FIF Group Cabang Palembang. Rata-rata jawaban tertinggi responden sebesar 3,61 (3,41-4,20 = Diberdayakan) untuk pernyataan "PT. FIF Group Cabang Palembang menetapkan kebijakan komunikasi terbuka melalui breefing”, artinya rata-rata jawaban adalah baik. Hal ini menandakan bahwa memang ada kebijakan komunikasi terbuka memalui breefing. Tingginya pernyataan ini karena diadakan komunikasi terbuka sekaligus diskusi khususnya bagi para pekerja lapangan seperti verivier, field collectoer dan field remidial.

Selanjutnya, tanggapan terendah responden sebesar 3,51 (3,41-4,5 = Diberdayakan) untuk pernyataan "PT FIF Group Cabang Palembang menciptakan kesempatan untuk pelatihan silang bagi Saudara sebagai karyawan”, artinya rata-rata jawaban adalah baik. Hal ini menandakan bahwa ada di beberapa bagian yang melakukan pelatihan silang misalnya di administrasi dan marketing, administrasi dan remidial atau collection.

Tabel 7. Tanggapan Karyawan Terhadap Keseluruhan Pemberdayaan

\begin{tabular}{clcc}
\hline No & Dimensi Pemberdayaan & Rerata & Keterangan \\
\hline 1 & Desire & 3,39 & diberdayakan \\
2 & Trust & 3,39 & diberdayakan \\
3 & Confident & 3,47 & diberdayakan \\
4 & Credibility & 3,61 & diberdayakan \\
5 & Accountability & 3,77 & diberdayakan \\
6 & Communication & 3,56 & diberdayakan \\
& Rerata & 3,53 & diberdayakan \\
\hline
\end{tabular}

Sumber: Penelitian, 2015.

Rerata jawaban responden secara keseluruhan sebesar 3,53 (3,41-4,20 = Diberdayakan). Hal ini menunjukkan bahwa memang ada pemberdayaan karyawan yang efektif dan baik pada PT FIF Group Cabang Palembang. Rata-rata jawaban tertinggi responden sebesar 3,77 (3,41-4,20 = Diberdayakan) untuk pernyataan "accountability", artinya rata-rata jawaban adalah baik. Hal ini menandakan bahwa memang ada pertanggung jawaban karyawan pada wewenang yang diberikan, dengan menetapkan secara konsisten dan jelas tentang peran, standar dan tujuan tentang penilaian terhadap kinerja karyawan, tahap ini sebagai sarana evaluasi terhadap kinerja karyawan dalam penyelesaian dan tanggung jawab terhadap wewenang yang diberikan melalui jalur pelatihan, ukuran tugas atau target yang jelas, dan adanya bantuan kepada karyawan dalam penyelesaian beban kerja. Tingginya pernyataan ini karena memang karyawan bertanggung jawab dalam bekerja misalnya dengan lembur. Berikutnya, Rata-rata jawaban terendah responden sebesar 3,39 (3,41-4,20 = Diberdayakan) untuk pernyataan "Desire" dan "Trust artinya rata-rata jawaban adalah baik. 
Implikasi Strategis. Pemberdayaan (empowerment) adalah proses membangun dedikasi dan komitmen yang tinggi sehingga organisasi itu bisa menjadi sangat efektif dalam mencapai tujuan-tujuannya dengan mutu yang tinggi. Dalam organisasi yang telah diberdayakan akan tercipta hubungan di antara orang-orangnya yang saling berbagi kewenangan, tanggung jawab, komunikasi, harapan-harapan, dan pengakuan serta penghargaan.Berdasarkan hasil penelitian yang dilakukan di PT FIF Group Cabang Palembang tentang pemberdayaan karyawan masih ada beberapa hal yang dianggap belum maksimal. Beberapa hal yang dianggap belum maksimal tersebut antara lain dari dimensi desire yaitu kurang mendorong karyawan memikirkan strategi kerja karena sudah ditetapkan oleh pihak manajemen PT FIF Group. Upaya yang dapat dilakukan oleh PT FIF Group Cabang Palembang lebih mendorong karyawan memikirkan strategi kerja dalam meningkatkan produktivitas.

Selanjutnya, dari dimensi trust yang dianggap masih kurang adalah berpartisipasi dalam pembuatan kebijakan berkaitan dengan pekerjaan. Usaha yang dapat dilakukan oleh pihak manajemen PT FIF Group adalah memberi kesempatan kepada karyawan untuk memberikan saran dan ide kepada manajemen berkaitan dengan pekerjaan karyawan sehingga bisa menjadi masukan bagi pihak manajemen PT FIF Group dalam membuat kebijakan. Selanjutnya, meningkatkan peran IKA untuk menggali ide dan saran serta dilibatkannya karyawan dalam penyusunan rencana operasional, rencana strategis, pembuatan visi dan misi setiap departemen yang nantinya ditetapkan sebagai kebijakan PT FIF Group. Berikutnya, hal yang dianggap masih kurang dari dimensi confident adalah kurangnya pendelegasian tugas.

Selain itu, penggalian ide dan saran masih kurang. Upaya yang dapat dilakukan oleh PT FIF Group Cabang Palembang untuk lebih meningkatkan dan mendorong karyawan untuk memberi ide dan saran berupa strategi bagaimana cara untuk bekerja lebih efektif dan efisien. Caranya adalah karyawan diminta untuk untuk mengidentifikasikan masalah, dan membuat cara penyelesaian yang paling efektif dan efisien. Ini akan dikompetisikan dan bagi yang memiliki ide dan saran yang memberikan kontribusi yang paling baik akan diberikan penghargaan berupa reward dan saran serta ide yang terbaik akan diterapkan ke semua region di Indonesia bahkan seluruh grup Astra.

Pada dimensi credibility hal yang dianggap masih kurang adalah bantuan menyelesaikan perbedaan-perbedaan dalam penentuan tujuan dan prioritas karena tujuan dan prioritas kerja bagi setiap karyawan sudah ditetapkan oleh PT FIF Group berupa target kerja baik itu penjualan atau penyelesaian laporan administrasi. Usaha yang perlu dilakukan oleh manajemen PT FIF Group Cabang Palembang membuat dan menetapkan secara baku semua tujuan dan prioritas kerja dalam bentuk buku SOP dan Buku Peraturan Perusahaan. Buku tersebut isinya wajib dipahami dan dikuasai oleh semua karyawan untuk dilaksanakan oleh karyawan sesuai dengan bagian dan bidang kerjanya. Selanjutnya, memberikan reward baik berupa uang atau dalam bentuk lainnya bagi karyawan yang mampu melaksanakan dan melampaui tujuan dan prioritas kerja.

Pada dimensi accountability hal yang dianggap masih kurang adalah karyawan tidak dilibatkan dalam penentuan target kerja. Usaha yang perlu dilakukan oleh manajemen PT FIF Group Cabang Palembang adalah mewajibkan karyawan untuk mencapai target kerja yang telah ditentukan. Manajemen PT FIF Group Cabang Palembang akan memberikan Surat Peringatan (SP) bagi karyawan yang tidak sampai target, bahkan pemutusan hubungan kerja jika masih juga tidak mencapai target. Sedangkan bagi karyawan Back Office diberi Surat Peringatan (SP) agar termotivasi untuk mencapai target kerja misalnya 
menyelesaikan laporan adminsitrasi dan keuangan sesuai dengan deadline yang telah ditentukan.

Dari dimensi communication hal yang masih dianggap kurang adalah kesempatan untuk pelatihan silang yang hanya diperuntukkan bagian administrasi dan marketing, administrasi dan remidial atau collection. Usaha yang perlu dilakukan oleh manajemen PT FIF Group Cabang Palembang memberikan pelatihan silang untuk bagian lainnya. Selanjutnya dilaksanakan breefing setiap pagi oleh masing-masing Section Head untuk mereview pekerjaan dan pencapaian target kerja karyawan, serta mensosialisasikan rencana (planning) atau target kerja setiap hanrinya untuk dilaksanakan sekaligus dilakukan coaching dan konseling bagi para karyawan. Selanjutnya menetapkan tema morning talk yang dilaksanakan setiap minggu dengan dengan melakukan sharing masalah yang terjadi dari setiap departemen. Selain itu, mengadakan gathering bersama karyawan dan top manajemen setiap bulan untuk melakukan review pencapaian target bulan lalu dan membahas rencana target bulan berikutnya yang harus dicapai oleh karyawan.

\section{PENUTUP}

Simpulan Berdasarkan hasil penelitian yang telah dilakukan pada PT FIF Group Cabang Palembang tentang pemberdayaan karyawan, maka dapat disimpulkan, secara keseluruhan pemberdayaan bagi karyawan pada PT FIF Group Cabang Palembang sudah baik. Pemberdayaan karyawan yang paling dominan adalah accountability. Dari hasil penelitian juga diketahui pemberdayaan karyawan yang terendah adalah trust dan confident. Dimensi desire pada umumnya sudah baik. Tetapi kurang dorongan pada karyawan untuk memikirkan strategi kerja karena sudah ditetapkan oleh manajemen PT FIF Group. Dimensi trust pada umumnya sudah baik. Tetapi semua kebijakan kerja sudah ditentukan oleh pihak manajemen PT FIF Group.Dimensi confident pada umumnya sudah baik. Tetapi tidak ada pendelegasian tugas.Dimensi credibility pada umumnya sudah baik. Semua tujuan dan prioritas sudah ditentukan oleh pihak manajemen.Dimensi accountability pada umumnya sudah baik.Tetapi kurang ada bantuan kepada karyawan dalam penyelesaian beban kerja dan jika pekerjaan menumpuk karyawan di haruskan lembur.Dimensi communication pada umumnya sudah baik. Pelatihan silang masih dalam intra bagian pada bagian administrasi dan marketing, administrasi dan remidial atau collection.

Saran. Saran yang diajukan oleh peneliti berdasarkan hasil penelitian yang telah dilakukan kepada pada PT FIF Group Cabang Palembang adalah, berkaitan dengan dimensi desire terdapat hal yang masih dianggap kurang yaitu kurang mendorong karyawan memikirkan strategi kerja karena sudah ditetapkan oleh pihak manajemen PT FIF Group. Usaha yang dapat dilakukan oleh PT FIF Group Cabang Palembang lebih memikirkan strategi kerja dalam meningkatkan booking dan market share, menekan Non Performance Loan (NPL), serta memikirkan strategi kerja agar menjadi lebih efektif dan efisien.Berkaitan dengan dimensi trust yang dianggap masih kurang adalah partisipasi karyawan dalam pembuatan kebijakan berkaitan dengan pekerjaannya. Usaha yang dapat dilakukan oleh pihak manajemen PT FIF Group Cabang Palembang adalah diberi kesempatan memberikan saran dan ide kepada manajemen berkaitan dengan pekerjaan karyawan sehingga bisa menjadi masukan bagi pihak manajemen PT FIF Group Cabang 
Palembang dalam membuat kebijakan. Selanjutnya, meningkatkan peran IKA untuk menggali ide dan saran serta dilibatkannya karyawan dalam penyusunan rencana operasional, rencana strategis, pembuatan visi dan misi setiap departemen yang nantinya ditetapkan sebagai kebijakan PT FIF Group Cabang Palembang.Berkaitan dengan dimensi confident adalah kurangnya pendelegasian tugas. Upaya yang dapat dilakukan oleh PT FIF Group Cabang Palembang jika memang sangat diperlukan. Penggalian ide dan saran masih kurang. Upaya yang dapat dilakukan oleh PT FIF Group Cabang Palembang adalah mendorong karyawan untuk memberi ide dan saran berupa strategi bagaimana cara untuk bekerja lebih efektif dan efisien. Caranya adalah karyawan diminta untuk untuk mengidentifikasikan masalah, dan membuat cara penyelesaian yang paling efektif dan efisien. Ini akan dikompetisikan dan bagi yang memiliki ide dan saran yang memberikan kontribusi yang paling baik akan diberikan penghargaan berupa reward dan saran serta ide yang terbaik akan diterapkan ke semua region di Indonesia bahkan seluruh grup Astra. Berkaitan dengan dimensi credibility hal yang dianggap masih kurang adalah bantuan menyelesaikan perbedaan-perbedaan dalam penentuan tujuan dan prioritas karena tujuan dan prioritas kerja bagi setiap karyawan sudah ditetapkan oleh PT FIF Group Cabang Palembang. Usaha yang perlu dilakukan oleh manajemen PT FIF Group Cabang Palembang membuat dan menetapkan secara baku semua tujuan dan prioritas kerja dalam bentuk buku SOP dan Buku Peraturan Perusahaan. Buku tersebut isinya wajib dipahami dan dikuasai oleh semua karyawan untuk dilaksanakan oleh karyawan sesuai dengan bagian dan bidang kerjanya. Selanjutnya, memberikan reward bagi karyawan yang mampu melaksanakan dan melampaui tujuan dan prioritas kerja.Berkaitan dengan dimensi accountability hal yang dianggap masih kurang adalah karyawan tidak dilibatkan dalam penentuan target kerja. Usaha yang perlu dilakukan oleh manajemen PT FIF Group Cabang Palembang adalah mewajibkan karyawan untuk mencapai target kerja yang telah ditentukan. Manajemen PT FIF Group Cabang Palembang akan memberikan Surat Peringatan (SP) bagi karyawan yang tidak sampai target, bahkan pemutusan hubungan kerja jika masih juga tidak mencapai target. Sedangkan bagi karyawan Back Office diberi Surat Peringatan (SP) agar termotivasi untuk mencapai target kerja misalnya menyelesaikan laporan sesuai dengan deadline yang telah ditentukan. Dimensi communication ada hal yang dianggap masih kurang adalah kesempatan untuk pelatihan silang. Usaha yang perlu dilakukan oleh manajemen PT FIF Group Cabang Palembang memberikan pelatihan silang untuk semua bagian. Selanjutnya dilaksanakan breefing setiap pagi oleh masing-masing Sub Region Head untuk review pekerjaan dan pencapaian target kerja karyawan, serta mensosialisasikan rencana (planning) atau target kerja untuk dilaksanakan sekaligus dilakukan coaching dan konseling bagi para karyawan. Selanjutnya menetapkan tema morning talk yang dilaksanakan setiap minggu dengan dengan melakukan sharing masalah yang terjadi dari setiap departemen.

\section{DAFTAR RUJUKAN}

Anakwe, Uzoamaka P, James C Hall, and Susan M.Schor, (2000) "KnowledgeRelated Skill and Effective Management", International JournalofManpower, 21 (77): 566-579, @ MCB University Press.

Berrel,Mike,Phil Wright, and TranThi Van Hoa. (1999) “TheInfluenc Culture on Managerial Behaviour”. Journal of Management Development, 18 (7): 578-589, @ MCBUniversityPress. 
Brower, Michael J. (1995) Empowering Teams: What, Why and How Empowering in Organization. MCB University Press. 2: 12-23.

Byars dan Rue. (1997) Human resources and personnel management. Richard D Iriwin, Inc. Illinois.

Conger, J.A., and Kanungo, R.N. (1988) "The Empowerment Process: Integrating Theory and Practice", Academy of Management Review, 13: 471-482

Davis,T,R,V.,and Luthans, F. (1980) "Asocial Learning Approachto Organizational Behavior", Academy of Management Review. 5: 281-290

Debora. (2006) "Pengaruh Pemberdayaan Kerja dan Psikologis Terhadap Kepercayaan Organisasional dan Kepuasan Kerja Dosen Tetap Perguruan Tinggi Swasta”. Jurnal Manajemen dan Kewirausahaan, 8 (2): 61-71.

Dolatta. (2010) “Analisis Pengaruh Pemberdayaan Karyawan dan Kompensasi Terhadap Kepuasan Kerja PNS di Puskemas Bantal Kabupaten Mukomuko”. Tesis UNIB. Tidak Dipublikasikan.

Dvrye, Catherine. (2002) Good Servise Is Good Business: Seven Simple strategies for Succes. Prentice Hall. Australia.

KennethW.ThomasandBettyA.Velthouse,(1990)"CognitiveElementsofEmpowerment:An Intrepetive Model of Intrinsic Task Motivation", Academy of Management Review. 15: 666- 681.

Khan. (1997) “The key to being a leader company: empowerment”. Journal Personality and Participation, Jan/Peb. p. 44-50.

Motowidlo, Stephan J., and Walter C Borman. (2000) ContextualPerformance and Organizational Citizenship Behavior in Human Resource. Human Resource Management Review. 10 (1): 1 - 2, Elsevier ScienceInc.

Noe, et al. (1997) Fundamental of Human Resource Management, Second Edition. McGraw-Hill Irwin.

Potterfield, Thomas (2000) The Business of Employee Empowerment : Democracy and Ideology in the work place” Bureau of Labor Statistics. U.S. Departemen of Labor. Vol 123. No. 2. (February 2000), PP 49-50.

Robbins, P. Stephen. (2006) Perilaku Organisasi. Edisi Lengkap Bahasa Indonesia Jakarta. PT. Indeks, Kelompok Gramedia.

Ratnawati, Intan. (2004) “Upaya Pemberdayaan Karyawan: Suatu Pendekatan Untuk Menumbuhkan Motivasi Kerja Intrinsik”. Juma Studi Manajemen\&Organisasi, Vol.1, No.1, Januan 2004

Seibert, E. Scott.et.al (2004) "Taking Empowerment to the Next Level: A Multiple-Level Model of Empowerment, Performance, and Satisfaction”. The Academy Of Manajement Journal. Vol 47, No. 3 (Jun.2004) PP33249.

Sedarmayanti. (2000) Sumber Daya Manusia dan Produktivitas Kerja. Mandar Maju. Bandung.

Sekaran, Uma, (2000) Research Method For Business. USA. John Willey and Sons Inc.

Singarimbun, M dan Effendi. (2002) Metode Penelitian Survey. Jakarta. LP3ES.

Wiberforce. (2000) "Gaining of Competitive Advantage Trough Employee Empowerment”. Gajah Mada International Journal Business. 2 (1): January. 